\title{
Michał Wenklar
}

ORCID: https://orcid.org/0000-0002-4965-9290

Historical Research Office of the Institute of National Remembrance, Krakow, Poland

Ignatianum Academy in Krakow, Poland

\section{The Polish Church and the "Thaw" of 1956}

\begin{abstract}
The process of "thaw", developing in Poland after the death of Joseph Stalin, for a long time did not include the aspect of religious freedom. Demands to restore the possibility of free worship, teaching religious education, and, above all, the release of the Primate Cardinal Stefan Wyszyński, were always present in the society, as evidenced by school strikes or slogans appearing during the Poznan events of June 1956. The changes of October 1956, initiated by the $8^{\text {th }}$ plenary of the Central Committee of the Polish United Workers' Party, led to an improvement in state-Church relations and implementation of the most important postulates of the Church, including the return of the Primate to Warsaw, the reinstatement of religious education in schools, and the return of chaplains to prisons and hospitals. The authorities, however, did not treat the above as part of a binding agreement. As early as in the 1957 and 1958 activities restricting the functioning of the Church began. The symbolic markings of the process were the attack on the Primate's Institute at Jasna Góra in 1958 and the withdrawal of consent for the construction of the church in Kraków's Nowa Huta. Finally, in 1961, religious education was removed from schools, and in 1962 a separate department of the Security Service was established for the sole purpose of the fight against religion. Although the practices of the Stalinist period did not make their comeback, the 1956 thaw appeared to be only a short episode in a constant conflict between the communist state and the Roman Catholic Church.
\end{abstract}

\section{Keywords}

Catholic Church, Polish People's Republic, state-church relations, thaw, Stefan Wyszyński, Władysław Gomułka 
1.

The death of Joseph Stalin on 5 March 1953 heralded the beginning of the socalled 'thaw', the process of moving away from the Stalinist, fully totalitarian version of the communist system. That process was a lengthy one, interrupted by subsequent paroxysms of the authorities attempting to maintain control, both in the USSR and in other countries of the Soviet bloc. For the actual end to be put to mass repression one had yet to wait. Worth recalling is the fact that the greatest blow to the Polish Church - the arrest of Primate Stefan Wyszyński was dealt almost six months after the death of the USSR leader. And the first symptoms of the thaw were not quite related to the Church.

The Polish thaw included several stages and events. Taken at the $2^{\text {nd }}$ Congress of the Polish United Workers' Party in March 1954 was a decision to introduce changes, modelled on the de-Stalinization processes taking place in the USSR. First of all, the already launched economic policy reform was upheld, thus moving away from strenuous industrialization and increasing production of consumer goods, the latter having higher priority for the average citizen. Secondly, the most important state and party functions were separated - the former First Secretary of the Central Committee of the Polish United Workers' Party and Prime Minister Bolesław Bierut remained the party's superior, while Józef Cyrankiewicz was the head of government. From September 1954, Radio Free Europe broadcast a programme of Józef Światło, former lieutenant colonel of the secret police, unmasking the cruelty of the system and corruption of the communist elites. ${ }^{1}$ These accelerated the reform of the repression apparatus - a secret meeting of the Political Bureau of the Central Committee of the Polish United Workers' Party was held in November, during which the blame for the terror was put on the management of the Ministry of Public Security, and the charges against the already incarcerated Władysław Gomułka were also questioned. In December that year, the Ministry of Public Security was liquidated, while the secret police was subordinated to the Committee for Public Security. ${ }^{2}$ As a consequence, a part of the discredited people were

${ }^{1}$ Z. Błażyński, Mówi Józef Światło. Za kulisami partii i bezpieki 1940-1955, Wydawnictwo LTW, Warszawa 2003; A. Paczkowski, Trzy twarze Józefa Światły. Przyczynek do historii komunizmu, Prószyński Media, Warszawa 2009.

2 These changes were modelled on the Soviet solutions. Already in March 1953, the Ministry of Public Security (MGB) in the USSR was liquidated, transferring its competences to the Ministry of Internal Affairs (MWD), and a year later, in March 1954, the State Security 
removed from their positions - including the removal of Minister Stanisław Radkiewicz and his reappointment as an insignificant Minister of State Agricultural Farms. Some officers of the Ministry of Public Security found themselves put on trial for having violated the rule of law. ${ }^{3}$ One week from the liquidation of the Ministry of Public Security, Władysław Gomułka was released from prison. ${ }^{4}$

Among other signs of the thaw were: the liquidation of the Special Committee for Combatting Fraud and Economic Malpractice, the organization of the International Youth Festival in summer 1955 in Warsaw, or the publication of "Poem for Adults" by Adam Ważyk- which gave spur to the so-called "Ważyk's thaw". Generally, more or less from mid-1955, the censorship loosened, the press took up more and more of the so-far forbidden topics, and there would be published articles criticizing at least the shortcomings or failures of the system - red tape, waste, omnipotence of local cliques and hidden agendas, the unjust repression of the former Home Army members, or dreadfully low living conditions for workers. The leader in the arena was the "Po prostu" ("Just so") weekly, a body of the Union of Polish Youth, renamed in September 1955 as the "weekly of students and young intelligentsia". Even more information was offered by "Nowa Kultura" ("New Culture") and "Przegląd Kulturalny" ("The Culture Review"), or in the local press. ${ }^{5}$

It is precisely on the basis of reading the rationed press that the detained in Prudnik, Cardinal Wyszyński could see the ongoing changes. In his "Prison

Committee (KGB), established in the place of the former NKVD and formally subordinated to the MWD.

${ }^{3}$ Proces Romana Romkowskiego, Józefa Różańskiego i Anatola Fejginaw 1957 roku, p. 1, p. 2, ed. M. Jabłonowski, Faculty of Journalism and Political Science of the Jagiellonian University, Central Archive of Modern Records in Warsaw, the "Polska mniej znana 1944-1989" series, Warsaw 2011.

${ }^{4}$ See e.g. R. Terlecki, Miecz i tarcza komunizmu. Historia aparatu bezpieczeństwa w Polsce 1944-1990, Wydawnictwo Literackie, Kraków 2007, pp. 120-127.

${ }^{5}$ On the development of the thaw and the events of October 1956, see primarily: P. Codogni, Rok 1956, Prószyński i S-ka, Warsaw 2006; J. Kochanowski, Rewolucja między październikowa. Polska 1956-1957, Horyzont Znak, Kraków 2017; P. Machcewicz, Polski rok 1956, Mówią Wieki, Warsaw 1993; M. Tarniewski (J. Karpiński), Porcja wolności (październik 1956), Instytut Literacki, Paryż 1979, and as seen from a more popular perspective: P. Bojarski, 1956. Przebudzeni, Wydawnictwo Agora, Warsaw 2016. The Polish October was presented against a broader backdrop of the 1956 world events in the book by Simon Hall 1956: The world in revolt, Pegasus Books, 2016 (Polish edition: 1956. Rok rewolty, Wydawnictwo Poznańskie, Poznań 2016). 
Notes", on 9 August 1955, he noted: "A major attraction for us were the newspapers, which we continued to receive. [...] Thus, I received "Świat", "Przekrój”, "Stolica", "Problemy", and "Przegląd Sportowy" ["World", "Cross-Section", "Capital", "Problems", and "Sports Review"]. Everything was a revelation to us. It was a whole new way of writing, extraordinarily critical towards things that had been untouchable before; it was startling and provocative. How was it that today the press was allowed to discuss openly the sore spots in Citizens' Police [MO], the National Agricultural Administration [PGR], and the bankrupt Union of Polish Youth [ZMP]? Two years ago even to think these things was dangerous. Some radical change in strategy must have occurred to allow public opinion a voice. Between the lines there were even such messages as 'Do not stifle criticism.' It seemed today one could do what I had been hoping to accomplish sitting in prison for these past two years. [...] To understand what was happening, I read those few banal publications from beginning to the end, missing nothing, not even the advertisements. Because everything teaches us something and leads us to understand these new currents in Poland"6.

The new currents, however, circumvented the Church. Not only were the previous harassments not withdrawn, but further attacks were undertaken. Already in 1954 and 1955, the party was fighting for the final removal of religious education from schools. This campaign was only to gain strength in 1954. The authorities intensified the struggle against religion in the school instruction, stripping teachers of the religious education of their teaching qualifications. ${ }^{7}$ This was accompanied by the head teachers taking crosses off the classroom walls. Protests followed. However, as Antoni Dudek observed, "the main line of resistance of the Church towards the pressure exerted by the authorities has shifted [...] from the episcopate and curia to individual parishes." ${ }^{\prime 8}$ It was parents from individual parishes who signed petitions to the education departments at the district presidencies and provincial national councils, or to the Ministry of Education. The protests were expressed at the meetings of the parents' committees - "These speeches were loudly applauded, especially by all mothers. A secret police official from the Kraków voivodeship noted, "the character of the

${ }^{6}$ A freedom within. The prison notes of Stefan Cardinal Wyszyński, Aid to Church in Need, Sutton 1986, pp. 187-188.

${ }^{7}$ More on disputes concerning religious education see: H. Konopka, Religia w szkołach Polski Ludowej. Sprawa nauczania religii w polityce państwa (1944-1961), Wydawnictwo Uniwersytetu w Białymstoku, Białystok 1997.

${ }^{8}$ A. Dudek, Państwo i Kościół w Polsce 1945-1970, Wydawnictwo PiT, Kraków 1995, p. 38. 
applause was that of a manifestation and gave the impression that most of the people came to the gathering just to lend to the demonstration a strong and mass expression". In some villages, the mothers were hanging crosses in the classrooms again, in others the crosses were taken over from the school head teachers in order to have them stored in dignified conditions. Sometimes the youth would spontaneously begin saying a prayer before the lessons. In Zakopane, in December 1955, following a series of petitions and speeches demanding the reinstatement of religious education, one of the students tore down the portraits of Bierut and Rokossowski from the walls and painted crosses where they would previously hang. ${ }^{10}$

Even absence strikes occurred. In autumn 1955, for three days, children from Słopnice in the Limanowa district did not attend school as a protest against the removal of religious education. Strike threats were noted in Bochnia and in Rytro. In the autumn of 1956, parents did not send their children to school in several villages near Tarnów and in Łopoń near Brzesko. In January 1956 in Tarnów following the removal of religious education from two primary schools - a manifestation of some 300-400 parents took place, on the school walls were hanged posters demanding the reinstatement of religious education, and the school headmistress received threatening letters, including one containing a piece of string and a reminder of the fate of Judas. A similar manifestation took place at the same time in Mościce near Tarnów. ${ }^{11}$

At first the authorities did not accept such activities, and the press saw it as a manifestation of medieval fanaticism. ${ }^{12}$ When the aforementioned strike in Łopoń had already lasted two weeks, a journalist of "Dziennik Polski" (the largest daily in Małopolska) summarized the parents' struggle for religious education for their children in the following manner: "The reactive part of the clergy uses the present moment to catch some of the great breath of that freedom

\footnotetext{
${ }^{9}$ Ibidem, k. 99.
}

${ }^{10}$ AIPN Kr, 056/1, v. 17, Sprawozdania Sekcji 4 Wydziału III WUdsBP 1951-1956, Sprawozdanie Sekcji 4 Wydziału III za 4 kwartał 1955 r., Kraków, 24 XII 1955, k. 193-201; ibidem, Sprawozdanie Sekcji 4 Wydziału III za 1 kwartał 1956 r.

${ }_{11}$ M. Wenklar, Nie tylko WiN i PSL. Opór społeczny $w$ powiecie tarnowskim $w$ latach 1945-1956, Institute for National Remembrance, Towarzystwo Naukowe „Societas Vistulana”, Kraków 2009, pp. 369-370.

12 I. Marcisz, Konstytucyjne swobody i średniowieczny fanatyzm, „Dziennik Polski”, 20 IX 1956. 
that our country is now enjoying." ${ }^{13}$ So the progressing thaw - the great breath of freedom - did not concern the Church at the moment.

\section{2.}

The year 1956 brought about new events, which offered even more hopes. First, in February 1956, the cult of the individual and some of the Stalinist crimes were condemned at the 2oth Congress of the Communist Party of the Soviet Union in Moscow. The originally secret speech of the USSR leader Nikita Khrushchev was read in Poland at every party level, hence it soon became known to virtually everyone. On 12 March, at the end of the Congress, Bolesław Bierut, the First Secretary of the Central Committee of the Polish United Workers' Party, died. During the sixth plenary, the chairmanship of the party was taken over by Edward Ochab, a compromise candidate between the party branches - the Puławy group being the tactical supporters of deeper changes, and the "Natolin" group called hard-liners. At the April session of the Sejm (the Polish Parliament), free speeches were addressed. A law on amnesty was passed, pursuant to which about 35 thousand prisoners left prisons, in a great majority of cases this concerned political prisoners. But at the same time, the law on abortion was passed, extending the possibilities of terminating a pregnancy. In that case, five deputies from the pro-government PAX group decided to vote against the government bill, and two of its representatives, Jan Dobraczyński and Andrzej Wojtkowski, defended the Catholic standpoint in the parliamentary debate. ${ }^{14}$

The discussion on the rule of law and the April amnesty allowed for making an assumption that also the imprisoned and interned clergy would be granted freedom. In conversation with Cardinal Wyszyński in Komańcza the secretary of the bishops, Bishop Choromański raised "the most important matter", meaning the return of the Primate to Warsaw. The Primate, however, objected, considering "the most important matter" to be showing respect towards the rights of the Church, while his own fate was only one of the elements at play. What Wyszyński counted on was the possibility of reconstructing the Joint

${ }^{13}$ I. Marcisz, Konstytucyjne swobody i średniowieczny fanatyzm, „Dziennik Polski”, 20 IX 1956.

14 A. Czajkowska, O dopuszczalności przerywania ciązy. Ustawa z dnia 27 kwietnia 1956 i towarzyszace jej dyskusje, in: Kłopoty z seksem w PRL. Rodzenie nie całkiem po ludzku, aborcja, choroby, odmienności, ed. M. Kula, Warszawa 2012, pp. 150-151. 
Commission of the government and the episcopate, a conversation with the prime minister or the new First Secretary. His was an expectation that "on the basis of the present call for law and order, we could try to call for a reconsideration of the case of the removed bishops: Adamski with his suffragans, Archbishop Baziak of Kraków, Bishop Kaczmarek of Kielce, and me with my suffragans"15. But these hopes were vain. The authorities were not yet willing to talk to the Church. Letters of Bishop Choromański directed to the Speaker of the Sejm and the General Prosecutor's Office, or the amnesty were not enough to let Cardinal Wyszyński return to Warsaw. The Primate, in fact, accepted these letters as "very poorly drafted"16, nor did he intend to regain freedom prior to his bishops - "I could return as the last but never as the first." 17

A confirmation of the unyielding standpoint of the authorities was the speech of Jerzy Morawski - a member of the Pulawy branch, the one advocating change at the meeting of the Party Unit of the Polish Writers' Union in April 1956. He strongly refused any proposed concessions towards the Church, raising concerns that the demands of the Church would only go farther and farther: first, it was a Catholic magazine, then the release of the Primate, and soon there would be demands to abolish the decree of February 1953 on the assignment of Church posts. "We shall not accept such freedom of speech," said Morawski, thus indicating that even the liberal part of the party was not yet ready for concessions in this area. ${ }^{18}$

Despite such a hostile position, the Episcopate, aware of the progressing thaw, tried to incorporate its postulates into the political debate. On 22 May, Bishop Choromański sent Franciszek Mazur, the secretary of the Central Committee a list of the issues seen by the Church as those of utmost importance. Bishop Choromański wrote about the issue of bishops imprisoned or removed from posts, about the needs to amend the decree of February 1953, to stop fighting religious education, to agree on pilgrimages and church processions, ensure pastoral care in hospitals and prisons, to do away with repressions against religious congregations and to stop harassing the clergy with excessive taxes. ${ }^{19}$ Despite unfavorable conditions, pastoral activity was already developing, and the Church

${ }^{15}$ A freedom within..., p. 247.

16 A freedom within..., p. 248.

${ }^{17}$ A freedom within..., p. 247.

18 A. Dudek, Państwo i Kościół..., p. 40.

19 A. Dudek, Państwo i Kościół..., pp. 40-41. 
was undertaking more and more initiatives with a view to attracting the youth. Demands to reinstate religious education and crosses in schools would appear both in sermons and in the demands posed by local communities. ${ }^{20}$

A clear signal that the issue of religious freedoms remained one of the fundamental demands of the society was the course of June 1956 in Poznan. Participants of the brutally suppressed manifestations often used religious symbolism. They would shout repeatedly, "We want God!" or "We demand religious education at school!". They chanted religious songs, including "In the shadow of your protection", "God Thou Hast Poland", or "We Want God". When, after having taken the building of Voivodeship Committee of the Polish United Workers' Party building, a number of boards spelling out the demands of demonstrators were placed on the fifth floor, one of them would read: "We want God". ${ }^{21}$ But Poznań was pacified, and several dozen people were killed. Prime Minister Józef Cyrankiewicz announced that, should someone put their hand again on the people's government, then "let him be sure that he would have that hand cut off by the people's government." At the same time, however, he admitted that one of the sources of the protest, apart from alleged provocative actions, were also the actual problems of the working populace. Yet he did not list religious matters as such problems.

The seventh plenary of the Central Committee of the Polish United Workers' Party, which took place in July 1956, marked the next stage of the progressing thaw. The first secretary Ochab and Prime Minister Cyrankiewicz would speak about distortions, failures, and conservatism of the party apparatus. The main resolution of the plenary promised fighting offred tape, deepening "socialist democracy", making political life more transparent and the reconstruction of the socialist rule of law, though it did not mention religious freedoms. The former resolutions condemning Władysław Gomułka were repealed, thus announcing his return to political life. The return of the Primate was, however, not mentioned.

Meanwhile, despite his detention, Cardinal Wyszyński continued to set the path for the Polish Church and remained an authority figure for millions of Poles. In 1956 the largest public manifestation of the society's attachment to the Church and the recognition of the Cardinal was held. On 26 August 1956 the vows of Jasna Góra were renewed. Already a few months before, on 3 May 1956, over 70,000 people had gathered there to celebrate the feast of the Queen

20 P. Machcewicz, Polski rok 1956..., pp. 60-62.

21 P. Machcewicz, Polski rok 1956..., p. 88, 94. 
of the Polish Crown. ${ }^{22}$ On that occasion, gathered at Jasna Góra were not a few dozen, but several hundred thousand Poles, their number reaching a million, according to some accounts. Before the ceremony, some rumours would have it that the authorities would release Cardinal Wyszyński and make it possible for him to come to Jasna Góra. ${ }^{23}$ This, however, did not happen, and the empty chair on the altar remained the symbol of the Primate. Cardinal Wyszyński, however, was present in spirit, and crowds of pilgrims kept repeating vows written by Cardinal, modelled on those made 300 years prior by King Jan Kazimierz in Lwów. There is no doubt that the Jasna Góra vows exerted the same effecton the events of October 1956 as the papal pilgrimage of 1979 on August 1980 - a celebration of national and ideological unity, a source of strength and solidarity, a declaration of great changes.

Already at the end of September, just before the climax of the thaw, the Church was dealt an unpleasant blow. When the Attorney General withdrew his bygone charges against the Silesian bishops Adamski and Bieniek, they tried to return to Katowice to take up their functions again. No consent was however granted and they had to leave the city. Bishop Choromański commented on the event, "The thaw has not yet come to the Church, but the avalanche is already on its way and it is for no one to stop it." ${ }^{24}$

\section{3.}

An avalanche of successive events was only to gain pace in late October 1956. On Friday 19 October, a session of the Eighth Plenum of the Central Committee of the Polish United Workers' Party began. The party adopted the reform programme and appointed Władysław Gomułka the new first secretary of the Central Committee. Worried by these developments, the Soviets launched intervention activities - tanks were sent on their way to Warsaw from Soviet army bases in Poland, and the delegation of the highest USSR authorities headed by Nikita Khrushchev landed in the Polish capital city. Despite hostile behaviour and conversations, Gomułka managed to convince the intruders that reforms

22 P. Machcewicz, Polski rok 1956..., p. 155.

${ }^{23}$ J. Zawieyski, Dzienniki, v. 1, Wybór z lat 1955-1959, Ośrodek Karta, Warszawa 2011, p. 282.

${ }^{24}$ As cited in: A. Dudek, Państwo i Kościót..., p. 42. 
were necessary in order to maintain power, and at the same time that he was the guarantor of certain limits of change, above all, in terms of maintaining the monopoly of the Polish United Workers' Party and the presence of Poland in the Soviet bloc. Satisfied with such an outcome, the delegation flew off, while the Soviet troops stayed on, only to leave for their bases after a few days. The October Revolution was beginning - the society showed enthusiasm for the resolutions of the 8th Plenum and the return of Gomułka; rallies and attempts at spontaneous, grassroot implementation of the changes, those announced by the party and those expected by society, were taking place across the country.

The issues related to the Church and religion went practically undiscussed during the session of the 8th Plenum of the Central Committee of the Polish United Workers' Party, which, after all, was to set the direction for the development of the democratization process. However, in his key speech given on 20 October, Władysław Gomułka did raise this topic, though embedding it in a rather surprising context of agricultural cooperatives as a Polish path to socialism in the farmlands. The new first secretary declared that engaged in the process of searching and implementing the best forms of cooperatives should be those from outside of the party - all persons who "strengthen the socialist system, and the social justice system", including the "progressive Catholic movement". The following words were quoted on many occasions: "It is a poor idea that socialism should be built exclusively by communists, or people with materialistic social views."25 This was interpreted as a consent to the coexistence in the state of non-Marxist ideologies, and to the participation of Catholics in social and political life.

Gomułka did not make any mention of the Church-related issues either at the most important, biggest rally on 24 October at Plac Defilad in Warsaw. Participating in the event were some 400,000 persons, and the First Secretary of the Central Committee of the Polish United Workers' Party was applauded as the guarantor of a new path of democratization and sovereignty. Never did a communist leader in Poland enjoy such support as was the case of Gomułka during that rally. Something, however, marred his contentment. As Stanisław Staszewski, the first secretary of the Voivodship Committee of the Polish United Workers' Party in Warsaw, recalled, "the speeches had already been finished,

${ }^{25}$ W. Gomułka, Przemówienie wygłoszone na VIII plenum KC PZPR. Uchwała VIII plenum KC PZPR o aktualnych zadaniach politycznych i gospodarczych partii, „Książka i Wiedza”, Warszawa 1956, p. 29. 
when there were shouts heard: "Wy-szyń-ski, Wy-szyń-ski. Gomułka asked nervously: 'What are those shouts?' I replied: 'They are shouting, Wyszyński!' 'Finish the rally'. I am finishing it. People started to leave, but there was still a mass, some 70,000. And this mass raised cheers in honour of Wyszyński, who was still in Komańcza, not yet released. They chanted: 'Wyszyński! to the Political Bureau', of course, which in our time sounded like a paradox, but reflected the mood of society."26 These moods were born out by other rallies which took place all over Poland in the turbulent days - in towns and villages, in workplaces, at universities. Recurrent were the slogans demanding the release of Primate Wyszyński and bishops, and the return of religious education to schools. Such rallies took place, for instance, in Białystok, Elbląg, Gdańsk, Gliwice, Gniezno, Lublin, Nowy Sącz, Poznań, Toruń... ${ }^{27}$ Sometimes, the demands concerned reinstatement of the church holidays, radio broadcast of the holy mass, hanging crosses in institutions and offices, as well as abolition of the law on termination of pregnancy. Often, as in Nowy Sącz, teachers defending the concept of secular schools were prevented from making their point by wolf whistles. Crosses were often spontaneously hung, sometimes instead of portraits of high-rank party officials. ${ }^{28}$ As the case of Poznań showed, these voices and actions evidenced the defeat of the communist authorities in the battle for the hearts and the attempt to secularize the Polish society, which paradoxically in the mid-1950s was, especially in the case of the working class, more Catholic than before the war. ${ }^{29}$ Paweł Machcewicz wrote, religious symbolism and demands related to the Church were at the time "an important reference point facilitating identification, forming a sense of community". 30

At the same time, one should bear in mind that the most dynamic element that set the tone for the October events was the student environment, or, more broadly, the so-called October left-wing, which was far from any connections with the Church and its postulates did not coincide with the expectations of the Catholic majority of the society. This environment, associated with the journalism of the "Po prostu" ("Just So") weekly - student activists, young activists

${ }^{26}$ S. Staszewski, in: T. Torańska, Oni, Agencja Omnipress, Warszawa 1989, p. 390.

27 P. Machcewicz, Polski rok..., pp. 155-163, A. Dudek, Państwo i Kościół..., p. 43.

28 T. Biedroń, Wiec w Nowym Sączu w październiku 1956, „Rocznik Sądecki” (1999), no 27, pp. 236-240.

29 J. Kochanowski, Międzypaździernikowa rewolucja..., p. 198.

30 P. Machcewicz, Polski rok..., pp. 176-177. 
from university party organizations, or from Yugoslavian model-oriented party committees of big factories - was ideologically Marxist and mostly atheistic. Its expectation was the construction of socialism with a human face, not a Catholic Poland. If it defended the rights of the Church, then they were doing it in the name of the rule of law. They were, however, distrustful about religious education making its comeback to schools, and many of them would later find themselves supporting the secularization movement. ${ }^{31}$ Such standpoint is well evidenced by the October left-wing representative, Jacek Kuron. He recalled that when, at one of the rallies, the postulate "Poland is a Catholic country, and therefore we are demanding the release of Primate Stefan Wyszyński” was submitted to the resolution, it was rejected by Lechosław Goździk, charismatic leader of the Żeran workers. After his intervention, the resolution included the following words: "Poland is a socialist country and no innocent person will be imprisoned, therefore we demand the release of Primate Stefan Wyszyński." ${ }^{32}$

Resolving the case of Primate Wyszyński was the starting point for any talks on a new arrangement of relations between the Church and the state. On 24 October, after the Warsaw rally, Gomułka decided to talk to the cardinal. Two days later, two collaborators of the First Secretary, Władysław Bieńkowski and Zenon Kliszko went to Komańcza, where the Primate was being interned. In a long conversation about the situation of the Church in Poland and the harm suffered, Wyszyński set out conditions which had to be met in order for an agreement to be reached and his return to Warsaw. The conditions included the abolition of the decree on the filling of clerical posts, resuming the work of the Joint Commission, allowing the bishops to return, and restoring the independent Catholic press. ${ }^{33}$ The delegation, and later the Political Bureau of the Central Committee of the Polish United Workers' Party, accepted most of the demands. On 28 October Cardinal Wyszyński returned to Warsaw, and on the following day he gave the first speech to the jubilant believers before the Primate's Palace at Miodowa Street.

${ }^{31}$ See D. Gawin, Wielki zwrot. Ewolucja lewicy i odrodzenie idei społeczeństwa obywatelskiego 1956-1976, Znak, Kraków 2013, pp. 48-57.

${ }^{32}$ J. Kuroń, Wiara i wina. Do i od komunizmu, Niezależna Oficyna Wydawnicza, Warszawa 1990, p. 119.

${ }^{33}$ A. Dudek, Państwo i Kościót..., s. 44; Notes by Primate S. Wyszyński from his conversation with W. Bieńkowski and Z. Kliszko, in: P. Raina, Kościół w PRL. Dokumenty, v. 1, 1945-1959, Wydawnictwo „W drodze”, Poznań 1994, pp. 563-564. 
By the 8 November the Joint Commission of the Government and the Episcopate met. After a month of work, an agreement consisting of six items was announced: 1. annulment of the decree of 9 February 1953 on the appointment of clerical church posts; 2 . freedom of teaching religious education in primary and secondary schools at the request of parents, as an extracurricular subject, with the teachers' salaries paid by the state; 3 . providing religious care for the sick; 4. providing religious care for prisoners; 5. return of nuns displaced in 1953 from voivodeships: Opole, Wrockaw, and Katowice; 6. consent to five bishops established by the Vatican in the Western Territories of Poland. ${ }^{34}$

The majority of these arrangements was in fact implemented - Bishop Adamski and Bishop Bednorz returned to the diocese of Katowice, and Archbishop Eugeniusz Baziak returned to Kraków from the Tarnów's exile on 3 December $1956 .{ }^{35}$ More time was needed in the case of Bishop Kaczmarek, whose judgment was finally quashed only at the end of December, but who returned to his diocese only in April 1957. ${ }^{36}$ There took effect orders of the Ministry of Education on religious education ${ }^{37}$, and pastoral activities were actually launched in hospitals and prisons.

Parallel to the activities of Cardinal Wyszyński and the works of the Joint Commission, there was the pursuit of the policy - to some extent agreed with the Primate, though independent of him - of Catholic activists. The key roles would be taken up by the Kraków activists, among them Jerzy Turowicz, Antoni Gołubiew, and Stanisław Stomma, and the so-called "Fronda", or PAX activists, who had left the association not being able to accept Bolesław Piasecki's politics and thirdly, several Warsaw activists among whom was the writer Jerzy Zawieyski. Their goals included recovering "Tygodnik Powszechny" which had been handed over three years before to the PAX activists, creating a more widespread Catholic organization which could play a real role in shaping Poland's political life. On 25 October representatives of these circles founded the

${ }^{34}$ Communication of the Joint Commission of representatives of the Government and the Episcopate on the principles of regulating common relations, in: P. Raina, Kościót w PRL..., pp. 575-576.

35 J. Marecki, Archidiecezja Krakowska w latach 1912-1964 [in:] Kościół krakowski w tysiącleciu, joint ed., Wydawnictwo Znak, Kraków 2000, p. 414.

36 A. Dudek, Państwo i Kościót..., p. 50.

37 A. Dudek, Państwo i Kościót..., p. 47; Państwo gwarantuje obywatelom pelną wolność sumienia, „Dziennik Polski”, 8 XII 1956; Nauczanie religii w szkołach, „Tygodnik Powszechny”, 6 I 1957. 
National Club of Progressive Catholic Intelligence (OKPIK) in Warsaw. The president, who declared support for Władysław Gomułka and access of the OKPIK to the National Front, was Jerzy Zawieyski, while its vice-president was Jerzy Turowicz. ${ }^{38}$

In the final days of October, Turowicz, together with Gołubiew and Jacek Woźniakowski, were staying in Warsaw to conduct talks on recovering "Tygodnik Powszechny". They returned with the promise of retrieving the weekly. Jan Józef Szczepański, who was close to them, recalled the almost triumphant character of this return, "It is quite funny to see the people who had previously avoided Jerzy's eye at meetings, now heartily squeeze his hand and wink in confidence." ${ }^{39}$ Formally, the consent for the resumption of "Tygodnik" along with the approval of the appropriate allocation of paper was issued on 14 November. The first issue of the revived magazine came out on 25 December 1956. The programme texts of Stanisław Stomma and Stefan Kisielewski laid out the assumptions of neo-positivism, or the ideological justification for political activity of Catholics within the system of the Polish People's Republic: if in October 1956 there appeared a new party and state leadership, operating in accordance with the requirements of raison detat, then, having taken into account independent geopolitical factors, it should be supported. This involved two compromises. Firstly, consent to the continuation of the alliance with the USSR; secondly, consent to the implementation of the socialism reform programme represented by Gomułka. Thus, the so-called progressive Catholics from "Tygodnik" made as Roman Graczyk has put it - the accession to the communist-reformers' camp. ${ }^{40}$

In the final days of 1956, representatives of this movement began to form a network of Catholic Intelligentsia Clubs (KIK) - referring to the thawing wave of clubs of intelligentsia or young intelligentsia in various towns. The first ones were established in Warsaw and Krakow, and attempts were made to establish Catholic clubs also in other towns. According to the Ministry of the Interior,

${ }^{38}$ P. Kaźmierczak, Klub Inteligencji Katolickiej w Krakowie w latach 1956-1989, WSFP Ignatianum, Wydawnictwo WAM, Kraków 2009, pp. 13-14. Seealso: A. Friszke, Oaza na Kopernika. Klub Inteligencji Katolickiej 1956-1989, Biblioteka „Więzi”, Warszawa 1997, pp. 34-49.

39 J. J. Szczepański, Dziennik, v. 1, 1945-1956, Wydawnictwo Literackie, Kraków 2009, p. 652.

${ }^{40}$ S. Stomma, Idea i siła, „Tygodnik Powszechny”, 25 XII 1956; S. Kisielewski, Czy neopozytywizm?, ibidem. See R. Graczyk, Realizm polityczny „Tygodnika Powszechnego” (19451989), „Politeja” (2013), no 25, pp. 96-97. 
in mid-1957 around 100 clubs were founded nationwide. ${ }^{41}$ In the end, apart from Warsaw and Kraków, only three KIK Clubs survived - in Wrocław, Toruń, and Poznań.

The implementation of most postulates prompted Cardinal Wyszyński to express his support for the ruling team in the forthcoming parliamentary elections. After the meeting with Prime Minister Cyrankiewicz, which took place on 14 January through Jerzy Zawieyski, any last concerns were resolved, following which the Primate released a communication encouraging to take part in the vote. Cardinal Wyszyński instructed that participation in the vote was a duty of conscience. ${ }^{42}$ One should bear in mind that at the time there was only one electoral list, i.e. of the National Unity Front, which also included candidates put forward by the "progressive" Catholics. The country was ridden with propaganda persuading that only the victory of the Gomułka team would guarantee that the October gains would be preserved. Widespread were slogans encouraging to vote without actually making any markings that is voting even without indicating specific candidates, and supporting the previously made list. In this context, the call of Wyszyński should be unambiguously read as an appeal for granting support to Władysław Gomułka and his candidates. Never before, nor later in the Polish People's Republic did the Church lend such strong a support to the ruling party. ${ }^{43}$

\section{4.}

The early 1957 could still offer hope that in the state-church relations there was indeed normalization, that despite the monopoly of the communist party, red tape pervading socialism, and the fact that Poland was still part of the Soviet bloc, the Church enjoyed freedom in pursuing pastoral activities. In addition to the aforementioned items included in the agreement with the authorities, it was possible to achieve favourable taxation conditions for the clergy and church legal entities. The issue of church constructions having so far been blocked, was

${ }^{41}$ P. Kaźmierczak, Klub Inteligencji..., p. 16.

42 A note by Primate S. Wyszyński from his conversation with Prime Minister Cyrankiewicz, in: P. Raina, Kościół w PRL..., pp. 581-582; Communication of the Episcopate on the elections, in: ibidem, p. 583.

43 A. Dudek, Państwo i Kościół..., p. 50. 
regulated - in 1957, 133 permits for the construction of churches was granted. The Circular of the Ministry of the Interior of June 1957 on the principles of public assembly enabled the organization of pilgrimages and processions. The Church also regained part of the real property taken over by the state. The Sejm included five representatives of Catholic circles who soon formed a joint deputies' circle. Each of them achieved better results in their respective constituencies than the party's candidate, and Stanisław Stomma, listed fifth in Kraków, obtained the best result in the entire voivodship, having received $97.33 \%$ of votes. In June 1957 , the first issue of the "Znak" monthly was published after it had ceased to be so in 1953, which coincided with "Tygodnik Powszechny" being taking over from its former editorial office. It lent its name to the "Znak" movement, thus linking the circles of "Tygodnik Powszechny", the "Znak" monthly, KiK and the Circle of Catholic Deputies “Znak”. In 1959, this group was supplemented by the Znak Public Publishing Institute, thus breaking the monopoly on publishing religious literature of the "PAX" Publishing Institute. At the same time, in February 1958, Tadeusz Mazowiecki's "Więź", the second magazine of the Catholic intelligentsia, marked its existence. The smaller, though symbolically important, achievement was the return of the altar by Wit Stwosz to the St. Mary's Basilica in Kraków, kept upon its recovery from the Germans at the Wawel castle. ${ }^{44}$ Of the most important postulates, only two remained unfulfilled - the "Caritas" charity organization, handed over to PAX activists, was not recovered, nor was it possible to reactivate the Faculty of Theology at the Jagiellonian University, which had been liquidated in 1954.

Teaching religious education - planned as an extracurricular subject and introduced at the parents' request - soon became a common phenomenon. At the end of 1957 , only 46 schools out of 26 thousand schools in Poland were fully secular, and in 800 of them there was no religious education only because there were no teachers. There were some cases - publicized and hyped up by the government agencies and the press - of retaliation against people fighting against the Church prior to October - this concerned especially provincial and local party activists, head teachers, or teachers. ${ }^{45}$ "Sow the wind, and you will harvest the storm", was Antoni Gołubiew's summary in "Tygodnik Powszechny" of the information about alleged intolerance and abuse observed upon introduction

${ }^{44}$ F. Machay, Ottarz Wita Stwosza wraca do Kościoła Mariackiego, „Tygodnik Powszechny”, 24 II 1957; Ottarz Wita Stwosza przekazano kościołowi Mariackiemu, „Dziennik Polski”, 1415 IV 1957.

45 Ibidem, p. 200. 
of religious education into schools. ${ }^{46}$ The populace took take their humiliation out. Religious education was reinstated, the crosses were hung again - sometimes in an ostentatious manner. At the rallies or open sessions of national councils, those councillors who had been previously involved in the school secularizing campaign, were now called Stalinists and were asked to step down. Demands were made to remove teachers or head teachers responsible for taking crosses off the school walls. Antoni Gołubiew, aided by Tadeusz Żychiewicz and Krzysztof Kozłowski from "Tygodnik Powszechny" ${ }^{47}$ would keep on responding to the accusations of violence against schools and teachers appearing in the press, arguments about the October values being threatened by intolerant Catholics, and appeals for "the abolition of violence and anarchy."

At the same time, the Church's pastoral activity was developing, and the society, feeling no longer threatened with repression, participated in large numbers in religious ceremonies and other events organized by clergy. The authorities, of course, closely watched this phenomenon, and wrote in internal reports about the "offensive of the clergy." ${ }^{49}$ Particularly worrying was for them the broad range of socio-cultural activities addressed to young people and the manifestations of religiosity and connections with the Church among state officials, police (MO) officers, and party activists. Cases of the dismissal of MO district commanders for having openly participated in church ceremonies were noted..$^{50}$ Mass religiosity was evidenced by pilgrimages to Jasna Góra sanctuary. They gave ample opportunity to manifest attachment to the teaching of the Church in areas important for the authorities, for instance, during the pilgrimage of doctors they raised the issue of the postulate of the abolition of the Act on termination of pregnancy. The first National Pilgrimage of Catholic Lawyers gained particular publicity. Among some 2,00o participating lawyers were attorneys, professors of law, but also judges and lawyers employed in various state agencies. ${ }^{51}$

\footnotetext{
46 S. Stomma, Kto sieje wiatr, ten zbiera burze, „Tygodnik Powszechny”, 10 II 1957.

47 T. Żychiewicz, O co właściwie chodzi?, „Tygodnik Powszechny”, 27 I 1957; K. Kozłowski, Na przykładzie szkoły TPD nr 2 w Katowicach, „Tygodnik Powszechny”, 17 II 1957.

48 I. Marcisz, Laicy laicyzacji, „Dziennik Polski”, 22 XII 1956.

49 A vivid, though not always favourable to Church description of the phenomenon by J. Kochanowski is available in the chapter: „Trwa ofensywa kleru”, czyli (chwilowe) odwrócenie ról w: Rewolucja międzypaździernikowa..., pp. 197-214.

50 A, Dudek, Państwo i Kościół..., p. 55.

51 J. Kochanowski, Rewolucja międzypaździernikowa..., pp. 206-207.
} 
5.

Following a brief period of the state-church relations becoming actually normal and ensuring fairly unrestricted religious activity, it appeared that for the partygovernment side, the concessions were only of tactical nature. As in the case of other October achievements, the authorities began to recover the lost areas. Teaching religious education in schools was again subjected to attacks. First so as to not violate the agreement - the allegedly social factors were invoked amongst them the Association of Atheists and Freethinkers founded at the beginning of 1957 and the Society of Secular Schools, i.e. the secular movement. When in response to these actions, Cardinal Wyszyński issued a "Pastoral Letter to Catholic Families", calling for children to be sent only to schools offering religious education, at the Joint Committee session, party representatives described it as an instance of intolerance. ${ }^{52}$

These were not the only harassments on the part of the state. Censorship started its activity again, the establishment of new parishes was hindered, the authorities imposed tariffs on charitable aid flowing to the Church from abroad, fuelled local conflicts in parishes and supported attempts to build the Polish Catholic Church by the priests at odds with the Church hierarchy.

The most serious sign of moving away from the agreement was the search carried out at the Primate's Institute of Jasna Góra Vows of the Polish Nation. The Institute was established on 3 May 1957 and provided facilities for Cardinal Wyszyński in the implementation of the Great Novena, a nine-year pastoral programme aimed at preparing Poles for the thousandth anniversary of the baptism of Poland. The authorities were concerned about the Novena programme, the publishing activity of the Institute, and the constantly growing pilgrimage traffic to Jasna Góra. On 21 July 1958, under the pretext of the allegedly illegal reproduction of texts, the prosecutor accompanied by the secret police officers conducted a search at the Institute. Without any records being made, the found documents and books were seized, including the officially issued "Spirit of $\mathrm{Hu}$ man Work" by Cardinal Wyszyński, as well as two typewriters. When the officers attempted taking publications from the kiosk standing in the monastery's courtyard, a crowd of anxious believers gathered there. Since the assemblers were

52 A. Dudek, Państwo i Kościół..., p. 59. For more on the secular movement see: Ł. Marek, M. Bortlik-Dźwierzyńska, Za Marksem bez Boga. Laicyzacja życia społecznego w Polsce w latach 1945-1989, Institute for National Remembrance, Katowice 2009. 
unwilling to obey the orders to disperse, in the evening they were attacked by the $\mathrm{ZOMO}$, and dispersed, and some of them were arrested. Such brutal intervention of the militia, combined with the intrusion of the most sacred place in Poland had not been seen in a long time. The following day, Władysław Gomułka, in an interview with Jerzy Zawieyski, the deputy from the Catholic group "Znak", accused Cardinal Wyszyński of calling for a religious war and said, "We shall not allow and shall nip in the bud every manifestation of a coup against the peace of our country. The Primate publishes bulletins and magazines at Jasna Góra, even books in which he attacks the government and people's authority. We have seized 60 bags of this anti-state illegal printouts." ${ }^{33}$ The Primate and Pauline friars of Jasna Góra made an official protest, describing the actions of the prosecutor's office as "an unprecedented insult and contempt of the religious feelings of the entire nation". The position of the authorities remained unwavering. Moreover, two Pauline friars and one employee of the Institute were sentenced to a few months of imprisonment and a fine for publishing uncensored publications. ${ }^{54}$

The attack on the Institute was a visible sign that something was brought to an end. The authorities no longer pretended to be willing to allow the free activity of the Church. In July 1958, the Central Committee of the Polish United Workers' Party issued a letter on the policy towards the Church to the party executive. The letter read about the alleged "offensive of the clergy aimed at inciting religious feuds in society and activating reactionary forces", against which the party and state bodies were supposed to put up a fight. ${ }^{55}$

Soon, the state's campaign to oust the cross and religious education from schools intensified. ${ }^{56}$ Sometimes these actions encountered considerable resistance. At the beginning of the school year of 1958, several groups of parents gathered in schools in several villages within the Kraków voivodeship protesting against the removal of crosses. In order to disperse the crowds, the authorities resorted to the use of Motorized Reserves of the Citizens' Militia (ZOMO), bludgeons and chemical agents. ${ }^{57}$ In the end, religious education was removed from

${ }^{53}$ J. Zawieyski, Dzienniki..., p. 547.

54 A. Dudek, Państwo i Kościół..., p. 70.

${ }^{55}$ A letter from the Central Committee of the Polish United Workers' Party to the party executives on the policy towards the Church, in: P. Raina, Kościół w PRL..., pp. 635-647.

56 A. Dudek, Państwo i Kościół..., pp. 74, 75.

57 A. Dudek, T. Marszałkowski, Walki uliczne w PRL 1956-1989, Wydawnictwo „Geo”, Kraków 1999, p. 88. 
schools in 1961. The development of sacred architecture was again blocked, and building permits which had already been granted were sometimes withdrawn. This led to riots and even street fights, as in Kraśnik Fabryczny in 1959 or in Nowa Huta in April 1960. ${ }^{58}$ Once again, repressions in the form of tax harassment occurred, and again attempts were made to drop the Trojan horse to the Church, this time being the "Caritas" Clergy Associations.

The pastoral work was restricted and the surveillance of the clergy was increased. In 1962, the $4^{\text {th }}$ Department in the Ministry of the Interior, responsible only for the control of the clergy was established. ${ }^{59}$ The government was gearing up for the next stage of the fight for the souls of Poles. In the Gomułka years it took the form of a dispute over the millennium, between the church celebrations of the Millennium of the Baptism of Poland and the party and government celebrations of the Millennium of the Polish State. The "portion of freedom" for the Church, as the 'thaw' and October 1956 as they were once termed by Jakub Karpiński, were brought to a halt. ${ }^{60}$

\section{Bibliography}

AIPN Kr, 056/1, t. 17, Sprawozdania Sekcji 4 Wydziału III WUdsBP 1951-1956.

AIPN Kr, 056/1, t. 24, Sprawozdania Wydziału III WUdsBP / KW MO 1955-1957.

„Dziennik Polski”
„Tygodnik Powszechny”

${ }^{58}$ For the exact course of events see: A. Dudek, T. Marszałkowski, Walki uliczne..., pp. 96107; T. Gąsiorowski, Walki o nowohucki krzyż w kwietniu 1960 r. w dokumentach Urzędu Bezpieczeństwa Publicznego przechowywanych $w$ archiwum Instytutu Pamięci Narodowej, in: Nowa Huta - miasto walki i pracy, ed. R. Terlecki, M. Lasota, J. Szarek, Kraków 2002, pp. 18-22; P. Jagło, Obrona Krzyża na os. Teatralnym 27 kwietnia 1960 roku. Aspekty prawne konfliktu, in: Nowa Huta dla Wolnej i Niepodległej, joint ed. Kraków 2014. See also: J. L. Franczyk, Pod presjq ateizacji. Kościół w Nowej Hucie w dokumentach Wydziału ds. Wyznań, in: Nowa Huta - miasto walki i pracy..., pp. 23-33; J. L. Franczyk, Na fundamencie krzyża. Kościót katolicki w Nowej Hucie 1949-1989, Kraków 2004, pp. 100-132.

59 See Instrukcje, wytyczne, pisma Departamentu IV Ministerstwa Spraw Wewnętrznych $z$ lat 1962-1989. Wybór dokumentów, edited and prepared by A. Dziurok, F. Musiał, Institute for National Remembrance, Wydawnictwo „Avalon”, Kraków-Katowice 2017.

${ }^{60}$ M. Tarniewski (J. Karpiński), Porcja wolności.... 
A freedom within. The prison notes of Stefan Cardinal Wyszyński, Aid to Church in Need, Sutton 1986.

Biedroń T., Wiec w Nowym Sączu w październiku 1956, „Rocznik Sądecki” (1999), no 27, pp. 236-240.

Błażyński Z., Mówi Józef Światło. Za kulisami partii i bezpieki 1940-1955, Wydawnictwo LTW, Warsaw 2003.

Bojarski P., 1956. Przebudzeni, Wydawnictwo Agora, Warsaw 2016.

Codogni P., Rok 1956, Prószyński i S-ka, Warsaw 2006.

Czajkowska A., O dopuszczalności przerywania ciąży. Ustawa z dnia 27 kwietnia 1956 i towarzyszace jej dyskusje, in: Kłopoty zseksem w PRL. Rodzenie nie całkiem po ludzku, aborcja, choroby, odmienności, ed. M. Kula, Warsaw 2012, pp. 150-151.

Dudek A., Marszałkowski T., Walki uliczne w PRL 1956-1989, Wydawnictwo „Geo”, Kraków 1999.

Dudek A., Państwo i Kościół w Polsce 1945-1970, Wydawnictwo PiT, Kraków 1995.

Franczyk J. L., Na fundamencie krzyża. Kościół katolicki w Nowej Hucie 1949-1989, Kraków 2004.

Franczyk J. L., Pod presja ateizacji. Kościół w Nowej Hucie w dokumentach Wydziału ds. Wyznań, in: Nowa Huta - miasto walki i pracy, ed. R. Terlecki, M. Lasota, J. Szarek, Kraków 2002, pp. 23-33.

Friszke A., Oaza na Kopernika. Klub Inteligencji Katolickiej 1956-1989, Biblioteka „Więzi”, Warsaw 1997.

Gawin D., Wielki zwrot. Ewolucja lewicy i odrodzenie idei społeczeństwa obywatelskiego 1956-1976, Znak, Kraków 2013.

Gąsiorowski T., Walki o nowohucki krzyż w kwietniu 1960 r. w dokumentach Urzędu Bezpieczeństwa Publicznego przechowywanych $w$ archiwum Instytutu Pamięci Narodowej, in: Nowa Huta - miasto walki i pracy, ed. R. Terlecki, M. Lasota, J. Szarek, Kraków 2002, pp. 18-22.

Gomułka W., Przemówienie wygłoszone na VIII plenum KC PZPR. Uchwała VIII plenum KC PZPR o aktualnych zadaniach politycznych i gospodarczych partii, „Książka i Wiedza”, Warsaw 1956.

Graczyk R., Realizm polityczny „Tygodnika Powszechnego” (1945-1989), „Politeja” (2013), no 25, pp. 96-97.

Hall S., 1956. Rok rewolty, Wydawnictwo Poznańskie, Poznań 2016.

Hall S., 1956: The world in revolt, Pegasus Books, 2016.

Instrukcje, wytyczne, pisma Departamentu IV Ministerstwa Spraw Wewnętrznych z lat 1962-1989. Wybór dokumentów, edited and prepared by A. Dziurok, F. Musiał, IPN, Wydawnictwo „Avalon”, Kraków-Katowice 2017.

Jagło P., Obrona Krzyża na os. Teatralnym 27 kwietnia 1960 roku. Aspekty prawne konfliktu, in: Nowa Huta dla Wolnej i Niepodległej, jointly edited, Kraków 2014.

Kaźmierczak P., Klub Inteligencji Katolickiej w Krakowie w latach 1956-1989, WSFP Ignatianum, Wydawnictwo WAM, Kraków 2009. 
Kochanowski J., Rewolucja międzypaździernikowa. Polska 1956-1957, Horyzont Znak, Kraków 2017.

Konopka H., Religia w szkołach Polski Ludowej. Sprawa nauczania religii w polityce państwa (1944-1961), Wydawnictwo Uniwersytetu w Białymstoku, Białystok 1997.

Kuroń J., Wiara i wina. Do i od komunizmu, Niezależna Oficyna Wydawnicza, Warsaw 1990.

Kuta C., „Działacze” i „Pismaki”. Aparat bezpieczeństwa wobec organizacji katolików świeckich w Krakowie w latach 1957-1989, Institute for National Remembrance, Wydawnictwo „Dante”, Kraków 2009.

Machcewicz P., Polski rok 1956, Mówią Wieki, Warsaw 1993.

Marecki J., Archidiecezja Krakowska w latach 1912-1964, in: Kościół krakowski w tysiącleciu, jointly edited, Wydawnictwo Znak, Kraków 2000.

Marek Ł., Bortlik-Dźwierzyńska M., Za Marksem bez Boga. Laicyzacja życia społecznego w Polsce w latach 1945-1989, Institute for National Remembrance, Katowice 2009.

Paczkowski A., Trzy twarze Józefa Światty. Przyczynek do historii komunizmu, Prószyński Media, Warsaw 2009.

Proces Romana Romkowskiego, Józefa Różańskiego i Anatola Fejgina w 1957 roku, p. 1, p. 2,

ed. M. Jabłonowski, Faculty of Journalism and Political Science of the Jagiellonian University, Central Archive of Modern Records in Warsaw, the „Polska mniej znana 1944-1989" series, Warsaw 2011.

Raina P., Kościół w PRL. Dokumenty, v. 1, 1945-1959, Wydawnictwo „W drodze”, Poznań 1994.

Szczepański J. J., Dziennik, v. 1, 1945-1956, Wydawnictwo Literackie, Kraków 2009.

Tarniewski M. (J. Karpiński), Porcja wolności (październik 1956), Instytut Literacki, Paris 1979.

Terlecki R., Miecz i tarcza komunizmu. Historia aparatu bezpieczeństwa $w$ Polsce 1944-1990, Wydawnictwo Literackie, Kraków 2007, pp. 120-127.

Torańska T., Oni, Agencja Omnipress, Warsaw 1989.

Zawieyski J., Dzienniki, v. 1, Wybór z lat 1955-1959, Ośrodek Karta, Warsaw 2011. 